\title{
Determinant Factors of Farmer's Willingness to Pay for Sustainable Land Management Practices Evidence with Homosha Benishangul Gumuz Region: Application with Multinomial Logit Model, Mixed Logit Model, and Conditional Logit Model
}

Melaku Tarekegn Takele ( $\nabla$ melakutar06@gmail.com ) University of Gondar College of Business and Economics

Mehammed Ibrahim Umer Assosa University

\section{Research}

Keywords: Sustainable land management's, willingness to pay, discrete choice experiment, crop-rotation, conserve-agriculture, terracing

Posted Date: August 11th, 2020

DOI: https://doi.org/10.21203/rs.3.rs-56133/v1

License: (1) This work is licensed under a Creative Commons Attribution 4.0 International License. Read Full License 


\title{
Determinant factors of farmer's willingness to pay for sustainable land
}

\section{management practices evidence with Homosha Benishangul Gumuz Region:}

\section{Application with multinomial logit model, mixed logit model, and conditional}

\section{logit model}

\author{
${ }^{1}$ Melaku Tarekegn Takele* $\quad{ }^{2}$ Mehammed Ibrahim Umer \\ ${ }^{1}$ School of Economics, College of Business and Economics, University of Gondar, P.o.box 196, \\ Gondar, Ethiopia, Email: melakutar06@gmail.com \\ ${ }^{2}$ College of Business and Economics, Economics Department, Assosa University, Benishangul \\ Gumuz, Ethiopia, P.O.BOX 18, Fax +251 5777507 84, Email: imu2019g@gmail.com \\ *Corresponding author
}

\begin{abstract}
The study examines factors affecting farmer's willingness to pay for sustainable land management practices in Ethiopia, The study uses primary data collected from 200 households randomly selected from four kebeles of districts in Ethiopia's Benishangul-Gumuz regional state with 4,800 observations (eight choices for each household). The choice experiment design was done using the $R$ software to efficiently generate an attribute and level combination using fractional factorial design. Data were analyzed using discrete choice models including multinomial logit model, mixed logit model, and conditional logit model using STAT-14. The findings showed that households were aware of the effects of using SLM and benefits of using a bundle of SLM. However, they were challenged by the costs of implementing a bundle of SLM and technologies related to it. Moreover, mean willingness to pay estimates is about 844 to 2540 Birr and incase of total willingness to pay households is not less than 66\% for a bundle of SLM. Crop-rotation attributes levels are negatively and significantly affect decision for SLM, while conserve-agriculture positively and significantly affects households' decision to adopt a bundle of SLM. Socio-economic (the type of crop, land size, landform, livestock, awareness about SLM and technologies) variables are found to be factors that determine decision to adopt SLM.
\end{abstract}

Keywords: - Sustainable land management's; willingness to pay; discrete choice experiment; crop-rotation; conserve-agriculture; terracing. 


\section{Introduction}

Nowadays, agriculturists in developing countries are confronting land scarcity and soil debasement. Within the overwhelmingly agrarian social orders of the world, one of most important foreboding dangers to nourishment furnish is herbal corruption, disintegration of croplands. Farmers are nevertheless destitute and nourishment frailty should be a great issue. The ability of the cultivating communities to support generation is, underneath genuine weight (Olana, 2014).

Coordination socio-economic standards with natural concerns is helpful to maintain or improve generation, lower degree of era hazard, secure attribute asset potential, avoid soil and water debasement, be financially reasonable, and be socially quality (Hagos \& Geta, 2016). The lion's share of populace of Ethiopia includes agriculturists and dwell is almost absolutely subordinate on horticulture. These days there is an expanding large request on arrive belongings due to giant increment inside variety of persons residing around it (Kifle, 2016). Arrive administration in Ethiopia has advanced into specific cultivating frameworks with different degrees of heightened (Kifle 2016). Within an equal way (Endalew, Muche et al. 2015) some soil and water renovation tactics have been utilized by using ranchers, most of which have established inside traditional records. Nevertheless, farm household's characteristics, choices making and their willingness to adopt choice land management's practices play an outstanding position on SLM. Therefore, assessing elements and willingness of farm households could shed light on policymaking of SLM. Additionally, land management choices are decided through many elements working at exceptional scales (plot, household, village, region, nation and international).

Today, land has reached quintessential point that serious doubts have been raised on capability of land to meet needs of a human. Furthermore, at some point in the remaining 20- 30 years, land has been degrading globally. This is, on the whole, the result of land mismanagement; land degradation threatens fertile land at some stage in the world. The penalties are alarming: food insecurity, pests, reduced availability of clean water, multiplied vulnerability of affected areas and their populations to local weather change, biodiversity loss, presence of invasive species, and a whole lot greater (Böttcher et al., 2012). As per UNDP, the stipulations in Africa are worsening with dirt storms, damaged watersheds, loss of forests, and decrease agriculture productivity, which is linked to human poverty, migration, and instability. (Nkonya, Mirzabaev, \& Von Braun, 2016). United Nations Development Program (UNDP) estimates \$42 billion in earnings and 6 million 
hectares of productive land are misplaced every year. As per UNDP, the stipulations in Africa are worsening with dirt storms, damaged watersheds, loss of forests, and decrease agriculture productivity, which is linked to human poverty, migration, and instability (Lanckriet et al., 2015). However, in Ethiopia, a few research employed valuation strategies to recognize farmer's willingness to pay for land activities the usage of CVM techniques Lamesgin, Degye, and Lemma (2017), and Abebe et al. (2019).

Valuation of natural resources like soil, forests, water sources, and fishery; and environmental services like clean air, recreations, and amenities are useful as such resources yield flows of service to people in increasing its welfare (Freeman, 1992). From this, it follows the basis for deriving measures of values is based on effect of hypothesized project on household's wellbeing. Environmental valuations, soil damage valuation, in this case, assess the social benefits of environmental goods and services forgone due to change in quality of soil or other words, measure contribution to human welfare that would have been if quality deterioration had not been occurred (Boyd, 2007). Revealed preference methods are based on actual behavior reflecting utility maximization subject to constraint.

However, revealed preference models cannot measure existence value or option value. In the stated preference category, there are different approaches such as choice experiment method, contingent valuation method, and conjoint analysis method. 
Random utility theory in which an alternative $i$ with true stimulus level is perceived with an error of $\mathrm{i}+\varepsilon \mathrm{i}$. The indirect utility function is decomposed into a utility function that depends solely on factors that are observed by the researcher and another utility function that represents all the factors that influence the consumer's choice. Again $\mathrm{Ui}=\mathrm{Vi}+\varepsilon \mathrm{i}$ and,for individual n, utility becomes $\mathrm{U}_{-}$in $=\mathrm{V} \_$in $+\varepsilon_{-}$inUi is the true but unobservable (latent) utility for alternative $\mathrm{i}, \mathrm{Vi}$ is the observable systematic component of utility, and $\varepsilon i$ is the factor unobservable to the researcher and treated as a random component. Assuming that the individual can choose between two alternatives, $i$ and $j$, then the probability that alternative $\mathrm{i}$ is chosen is given by,

$$
\operatorname{Pi}=\operatorname{prob}\left(U_{-} i>U_{-} j\right)=\operatorname{prob}\left(V_{-} i+\varepsilon_{-} i>V_{-} j+\varepsilon_{-} j\right)=\operatorname{prob}\left(V_{-} i_{-} V_{-}>\varepsilon_{-} i-\varepsilon_{-} j\right) \forall i \neq j
$$

From this, it can be seen that the higher probability for choosing an alternative, the larger difference in observed utility. Since probability is defined on a cardinal scale, so are the estimated utility scores (which is the reason why we obtain meaningful WTP estimates).

The foundation for any stated preference experiment is an experimental design. An experiment can be designed the observation of the effect upon one variable, a response variable, given the manipulation of the levels of one or more other variables. The manipulation of the levels of the variables does not occur haphazardly. Rather turn to a specialized form of statistics to determine what manipulations to make and when to make them. Thus we can say that the manipulations occur by design hence the name "experimental design". According to (Ryan, 2004) design of DCE, can be divided into several main stages.

\section{Methodology}

\section{Description of Study area}

Homosha is one of the 20 woreda in the Benishangul-Gumuz region of Ethiopia. The 2007 national census reported an entire population for this woreda of 21,744, of whom 11,219 were men and 10,525 was women; 875 or $4.02 \%$ of its population were urban dwellers. The popular of the residents said they were Moslem, with $69.28 \%$ of the population reporting they observed this belief, while $19.03 \%$ of the population were Protestant, $7.03 \%$ were Catholic, and $4.39 \%$ practiced Ethiopian Orthodox Christianity (CSA, 2008)

Based on figures from the CSA in 2007, the woreda was an estimated area of 645.78 square kilometers, Homosha has a population density of 20.1 people per square kilometer which is greater than the Zone average of 19.95.The 1994 national census reported a total population for this woreda of 9,762 in 2,261 households, of whom 5,008 were men and 4,754 was women; no urban dwellers 
were recorded. The prime ethnos conveyed in Homosha was the Berta with $99.5 \%$ of the population; they spoke Berta (99.5\%), and 99.5\% of the population were Muslim. Concerning education, $15.97 \%$ of the population were considered literate, which is less than the Zone average of $18.49 \% ; 14.29 \%$ of children aged $7-12$ were in primary school; $1.01 \%$ of the children aged $13-$ 14 were in a junior secondary school; and a negligible number of the inhabitants aged 15-18 were in senior secondary school. Concerning sanitary conditions, $2.8 \%$ of all houses had access to safe drinking water, and $16.8 \%$ had toilet facilities at the time of the census (CSA, 2008)

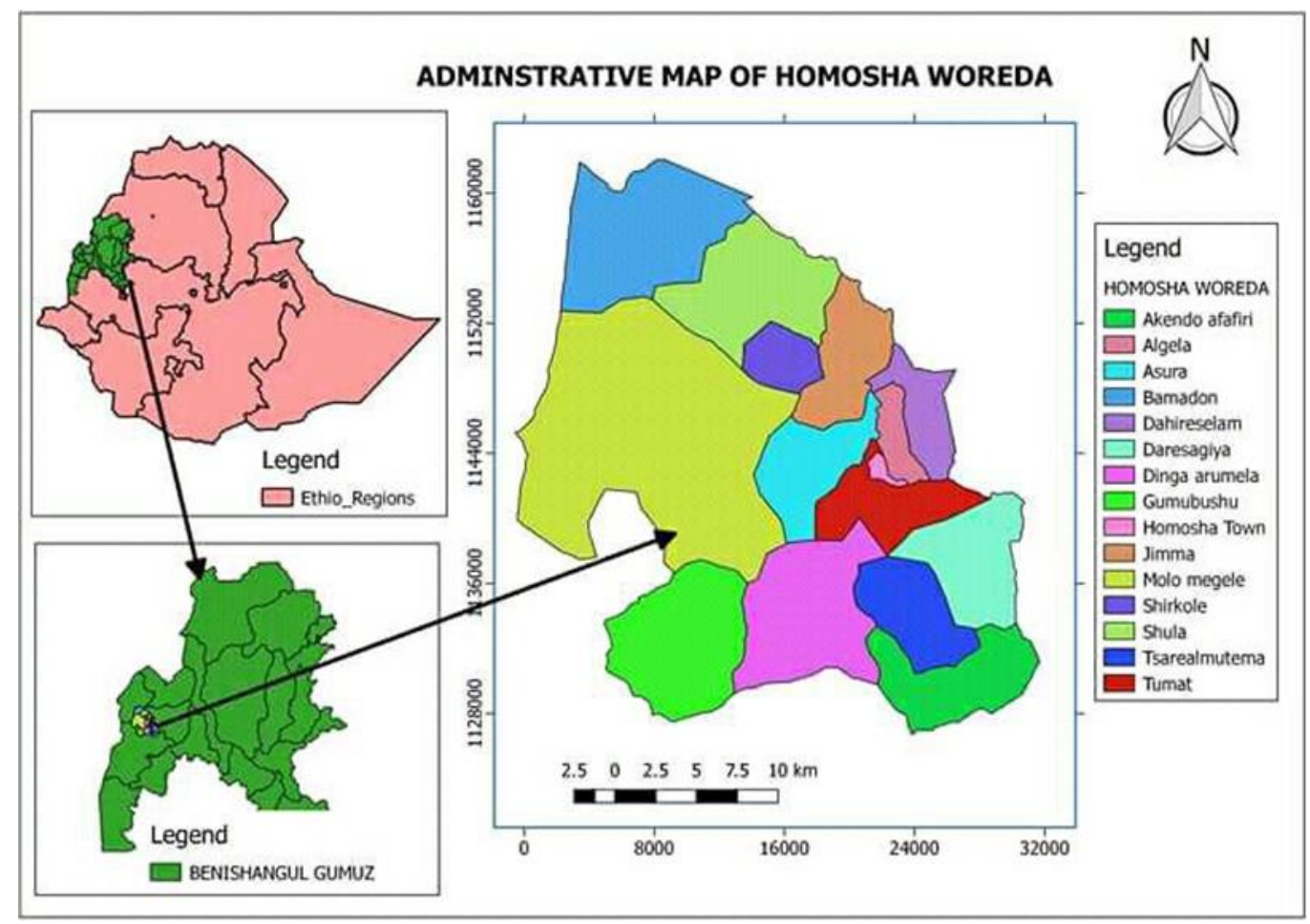

\subsection{Sampling procedure and sampling size determination}

The study selected four (4) kebeles using a random lottery method from fifteen (15) kebeles which are Shula, Alfashir, Darussalam, and Dunga kebeles. The reasons for adopting a simple random method are, all kebeles in the study area are homogenous in terms of landholding related culture, agriculture practices, and other factors concern SLM issues. Therefore, to determine required sample size, the study followed sample size requirements for discrete-choice experiments. Rule of thumb as proposed by(Johnson \& Orme, 2003)suggests that sample size required for main effects depends on number of choice set (t), number of alternatives (a), and he number of analysis cells or 
levels (c) and required sample (N), and given formula gives minimum required sample size for discrete choice experiments and formula should be multiply by number of choice set block if choice set is blocking according to the following equation: $\mathrm{N}>500 \mathrm{c} /(\mathrm{t} \times \mathrm{a})$

When considering the main effects, 'c' is equal to the largest number of levels for any of the attributes. When considering all two-way interactions, ' $\mathrm{c}$ ' is adequate to the most important product of levels of any two attributes. So the study has three alternatives including status quo(3), four attributes including monetary attributes(4),(two attributes have four levels and others two have two(2) levels), and the study has design sixteen16 choice set for each despondence with two(2) blocking. The sample size will be as follow: $(\mathrm{N}>500 \mathrm{c} /(\mathrm{t} \times \mathrm{a})) \times 2: \mathrm{N}=?, \mathrm{t}=16, \mathrm{a}=3, \mathrm{c}=3$, and $2=$ number of choice set block, $N>500(3 \times 3) /(16 \times 3)=93.75 \times 2=187.5 \approx 188$ minimum of sample size is required, therefore tacking into the account the burdens of discrete choice experiments investigation the study decide to use 200 sample size for 1964 households from randomly selected four kebeles of the targeted districts or from total of fifteen (15) kebeles. Then, using proportional sampling to household size, the calculated sample size is distributed for four, Shula(755) 77 , ALfashir(225) 23, Daresalam(447) 46 and Dunga(537) 55 The study used both qualitative and quantitative data collection methods to investigate in detail the issue. The quantitative data were collected by using questionnaires and qualitative data was collected through key informant structured interviews (using designed choice experimental variables). The study was used both multinomial logit for determinants of WTP analysis and discrete choice models (conditional logit, multinomial logit, and mixed logit ) to analyze study objectives very clearly, therefore both models were specified.

\section{The multinomial logit model}

The MNL model, developed by McFadden (1974), is by far most used multinomial model and can be considered as origin of multinomial models. The MNL model has a special property as it assumes independence of irrelevant alternatives (IIA). This implies that ratio of probabilities of choosing one alternative over another is unaffected by presence or absence of any additional alternatives in choice set. The IIA assumption provides some clear advantages as it makes the MNL model very simple to operate. Key assumptions underlying MNL model are (IID) that is unobserved effects, independent and identically distributed, independence of observed choices, and homogeneity of preferences (Hensher etal., 2005). 


\begin{tabular}{|l|l|l|l|}
\hline Variables & $\begin{array}{l}\text { Nature } \\
\text { variables }\end{array}$ & Measurements unit & Expected sign \\
\hline Dependent variables & & & \\
\hline lmp ${ }^{1}$ & Categorical & $\begin{array}{l}\text { (1, terracing 2, conserve agriculture } \\
3, \text { crop rotation 4, others ) }\end{array}$ & \\
\hline Independent variables & & & \\
\hline Age of household head & Continuous & In years & - \\
\hline Sex of household head & Dummy & 1 if male or, 0 otherwise & + \\
\hline Religion & Categorical & $\begin{array}{l}1 . \text { Orthodox 3. Protestant } \\
2 . \text { Muslim 4. Others }\end{array}$ & $+/-$ \\
\hline Marital Status & Categorical & 1 Single 2. Married 3. Divorced & \\
\hline Educational status & Categorical & $\begin{array}{l}1, \text { illiterate 2, primary } \\
3, \text { secondary 4, higher }\end{array}$ & + \\
\hline $\begin{array}{l}\text { The slope } \\
\text { land/landform }\end{array}$ & Categorical & 1, steep 2, gentle 3, flat & + \\
\hline Income & Continuous & Eth. Birr (ETB) & + \\
\hline family size & Continuous & Number & + \\
\hline $\begin{array}{l}\text { Perception } \\
\text { erosion }\end{array}$ & Dummy & 1 if Perceive, 0 otherwise & + \\
\hline $\begin{array}{l}\text { Extension } \\
\text { contact/training }\end{array}$ & Continuous & Number of days & + \\
\hline Access to credit & Continuous & Hectare & + \\
\hline Land size & Kg/hectare & + \\
\hline Fertilizer & In-person & + \\
\hline Off-farm/HH_size & In-person & + \\
\hline On-farm/HH_size & & + \\
\hline
\end{tabular}

\footnotetext{
${ }^{1}$ Types of SLM
} 


\begin{tabular}{|l|l|l|l|}
\hline $\begin{array}{l}\text { Agricultural production } \\
\text { spent }\end{array}$ & Categorical & $\begin{array}{l}\text { 1. Some for Personal consumption } \\
\text { and some for market } \\
\text { 2. For the market only 3. For personal } \\
\text { consumption only }\end{array}$ & $+/-$ \\
\hline Type of crop & Categorical & $\begin{array}{l}\text { 1. Teff 3. Barely 5. Maize } \\
\text { 2. Sorghum 4. Wheat 6. Others }\end{array}$ & $+/-$ \\
\hline
\end{tabular}

The multinomial logit model is an extension of the binary logit model. Given individual-specific covariates $\mathrm{xi}$, the probabilities for $\mathrm{J}$ choices are given by

$$
\operatorname{prob}\left(Y_{i}=j\right)=\frac{\exp \left(\beta_{\mathrm{j}} \mathrm{x}_{\mathrm{i}}\right)}{\sum_{\mathrm{k}=0}^{J} \exp \left(\beta_{\mathrm{k}} \mathrm{x}_{\mathrm{i}}\right)} j=0,1,2 \ldots J, i=1,2, \ldots . .12
$$

A convenience normalization is $\beta_{0}=0$, this arises because the probabilities sum to one, so only $\mathrm{J}$ parameter vectors are needed to determine the $\mathrm{J}+1$ probabilities. Therefore the probabilities $\operatorname{areprob}\left(Y_{i}=\frac{j}{x_{i}}\right)=\frac{\exp \left(\beta_{\mathrm{j}} \mathrm{x}_{\mathrm{i}}\right)}{1+\sum_{\mathrm{k}=0}^{J} \exp \left(\beta_{\mathrm{k}} \mathrm{x}_{\mathrm{i}}\right)} j=0,1,2 \ldots \ldots J, \beta_{0}=o$

$\mathrm{X}=\mathrm{i}(\mathrm{AGE}, \mathrm{SEX}, \mathrm{EDU}, \mathrm{FE}, \mathrm{SL}, \mathrm{IN}, \mathrm{FS}, \mathrm{PL}, \mathrm{EX}, \mathrm{CR}, \mathrm{LMP}, \mathrm{LS})$ and Yi = lmp

Summary of definition, measurement, and hypothesis of the Variables

Source: Own depiction (2020)

\section{Design of discrete choice experiment}

A DCE aims to estimate weights that respondents place on each of attributes which define the alternatives. A respondent acting rationally is predicted to gauge the choice s during a choice task and choose the alternative which provides the best relative utility (Hensher, Rose, \& Greene, 2005). When general utility theory is applied on agricultural producers for profit maximization paradigm, particularly within the existence of risk (Barry, Sherrick, \& Zhao, 2009).Thus, a farmer is expected to choose land management alternative A over $B$, if $U(X A, Z)>U(X B, Z), \ldots(13)$ where $U$ represents his/her indirect utility function from given land management alternatives, XA the attributes of land use $\mathrm{A}, \mathrm{XB}$ the Attributes of alternative $\mathrm{B}$, and $\mathrm{Z}$ the personal (e.g. sociodemographic and attitudinal) and property characteristics that influence the pastoralist's utility. Choices made in DCEs are analyzed using random utility theory, meaning a stochastic error term 
$\varepsilon$ is included in the utility function to reflect the unobservable factors in the respondent's utility function (Hensher et al., 2005).

Thus, farmers' will choose alternative A over $\mathrm{B}$, if $\mathrm{V}(\mathrm{XA}, \mathrm{Z})+\varepsilon \mathrm{A}>\mathrm{V}(\mathrm{XB}, \mathrm{Z})+\varepsilon \mathrm{B}, \ldots \ldots$ (14) where $\mathrm{V}$ is the measurable component of utility estimated empirically, and $\varepsilon \mathrm{A}$ and $\varepsilon \mathrm{B}$ reflect the unobservable factors in the farmers' utility function of alternatives A and B respectively. Design dimensions fundamentally influence the results of choice experiments and resulting recommendations (Rolfe, Windle, \& Bennett, 2008).

\section{Discrete Choice experiments and response format}

Responses in a DCE can take on different formats including 'pick-one', 'best-worse', and others. This research will apply the 'pick-one 'format. 'pick-one' better in real-life decision making, and it captures the first preference. 'Best-worst' also reveals the first preference but elicits additional preference information per choice (Lancaster, 1966). In a situation where the sample size is expected to be smaller, this poses a distinct advantage. Best-worst takes advantage of an individual's ability to identify extreme options and it is easy for respondents to understand (Flynn, Louviere, Peters, \& Coast, 2007). While imposing a higher cognitive burden on the respondent than 'pick-one', therefore, the study was to apply a "pick-one" format.

\section{Attributes and level}

\begin{tabular}{|l|l|l|}
\hline Attributes & Level & Coding \\
\hline Terracing(T) & Reduce soil erosion(1) and increase soil moisture(2) & 1 and 2 \\
\hline $\begin{array}{l}\text { Crop-rotation(CR) } \\
\text { Agriculture(CA) }\end{array}$ & $\begin{array}{l}\text { Reduce pests(1) and Increase soil fertility(2) } \\
\text { quality(2), } \\
\text { Improvement of air quality(3) and increase crop } \\
\text { yield (4) }\end{array}$ & 1 and 2 \\
\hline Total cost(TC) ETB & $250,500,750$ and 1000 & $1,2,3$ and4 \\
\hline
\end{tabular}

Source: Own depiction (2020) 


\section{Experimental designs}

The study would have four attributes (terracing, crop-rotation, total cost and conservation agriculture) of interest, two factors have two-level (2) and others two factors have four levels (4), $22 * 24=4 * 16=64$ experiments are needed for a full Factorial design. However, it is often impossible to run the full factorial design given available resources or will jeopardize a great amount of work. A design that contains a subset of factor level combinations from a full factorial design is called a fractional factorial design. The significance of effects found by using these designs is expressed using the statistical method; a fractional factorial design is often used as a screening experiment involving many factors to identify only those factors having large effects. By using R i386 3.1.3 statistics software, the computer has generated 16(sixteen) experimental choices set from a total of 64 full experiments. Even though 16(sixteen) out of 64 experiments are efficiency, providing all of the 16(sixteen) for respondents will be difficult and it leads to the respondent's fatigue bias, therefore the study block 16(sixteen) experiments into two size block to provide 8(eight) experiments for each two group of respondents, All DCEs constructed using a blocked factorial design for the estimation of the clear effects are always D-optimal and 100\% efficient(Jaynes, Ding, Xu, Wong, \& Ho, 2013).

\section{Statistical efficiency of choice experiments}

The efficient design has recently emerged as an alternative with new algorithms to facilitate the design. Efficient designs have been empirically shown to lead to smaller standard errors in model estimation at smaller sample sizes compared to orthogonal designs further, efficient designs are less restricted and easier to find than orthogonal designs, often enabling much smaller designs in terms of the number of choice sets (Ryan, 2004).

The aim was to estimate a random parameter logit (RPL) model, in which the random parameters describe heterogeneity in preferences. In stated choice surveys where respondents face multiplechoice tasks, correlations between choices need to be taken into account by considering the choices as panel data according to Train (1998). According to Bliemer and Rose (2010) generating efficient designs for the panel RPL model is extremely complex and mostly infeasible. However, they find that an efficient design for the multinomial logit (MNL) model is often also efficient for estimating the panel RPL model. Therefore, the study will generate an efficient design assuming an MNL model and use this design to Bayesian D-efficient design or D-optimality. 
The most widely used measure is the D-error measure (Huber and Zwerina, 1996), the lower this D-error, the more efficient the design, and is computed by taking the determinant of the AVC matrix (and scaled according to the number of parameters). Similarly, the A-error is the (scaled) trace of the AVC matrix, which is simply the sum of the diagonal elements representing (the squares of) the standard errors. Then the D-error and A-error are defined as

$$
\begin{gathered}
D-\text { error }=(\operatorname{det}(\Omega N))^{1 / K} \\
A-\text { error }=\frac{\operatorname{tr}(\Omega N)}{K}
\end{gathered}
$$

While minimizing the A-error scaling of the parameters may lead to different results (standard errors of large-valued parameters are typically larger, which may overshadow the minimization of the standard errors of small-valued parameters), the D-error is not sensitive to parameter scaling through the determinant. In this paper we will concentrate on minimizing the D-error however is expected to be $\leq 25 \%$, Therefore, to illustrate the optimality and efficiency of the generated fractional factorial experimental choice set, the study was used R i386 3.1.3 statistics software and "AlgDesign" Algorithmic Experimental Design, (Jaynes et al., 2013).According to the above explanation, the software has generated the following D-optimal criteria: $\mathrm{D}=0.2127797$ and $\mathrm{A}=$ 7.237037, therefore, the study can conclude that the generated fractional factorial choice set is optimal and affiance by $79 \%$.

\section{Choice Alternative design}

The alternatives in our DCE are of an unlabeled type and have generic titles (options 'A' and 'B') because this fits with the generic nature of the project's investigation of the role that attributes of land management's play in acceptance by farmers. Unlabeled designs have been shown to increase respondents' attention to attributes and more suitable for investigating trade-offs between attributes Flynn et al. (2007).

the choice set alternative design was generated using $\mathrm{R}$ i386 3.1.3 statistics software by adopting a fold over choice set design, a fold over design defined as a system-level change or cyclical shifting and it is a mirror image of others choice set of the original design was the result in a design that has a higher efficiency (Street, Burgess, Viney, \& Louviere, 2008).In this regard, the discrete choice experiment provides a panel of eight (8) choice sets for everyone From a given version 
(Table). Each choice set consists of two experimentally designed alternatives - labeled 'Option A' and 'Option B' and C a status quo alternative labeled 'No Action' which indicate the usual or traditional land management's by farmers or targeted households.

\section{Block1.1 Illustration of a choice set (sample of experiments)}

\begin{tabular}{||l|l|l|l||}
\hline Choice 1 & Alt1 & Alt2 & Alt3 (status-quo) \\
\hline \hline Terracing(T) & Reduce soil erosion(1) & Reduce soil erosion(1) & Shift cultivation \\
\hline Crop-rotation(CR) & Reduce pests(1) & Increase soil fertility(1) & Shift cultivation \\
agriculture(CA) & quality(2) & Improve soil structure(1) & Shift cultivation \\
\hline Total cost(TC) & $250 \mathrm{ETB}(1)$ & $500 \mathrm{ETB}(2)$ & Shift cultivation \\
\hline \hline \hline Which option would & & & \\
\hline you choose?
\end{tabular}

Source: Own depiction (2020)

\section{Random Parameters Logit Model}

Treating $V i$ as a conditional indirect utility function and assuming that utility is linearly additive, the observable utility for alternative $i$ can be written as $V_{i}=\beta_{x i} \rightarrow U_{i}=\beta_{x i}+\varepsilon_{i} \ldots$ (17)where $x i$ $=(x 1 i, x 2 i, \ldots, . x p i)$ is the vector of the attributes for alternative $i$ including a possible price attribute, and $\beta$ is the weighting (parameters) of the attributes(Ryan, 2004). When comparing (dividing) two attributes, marginal rates of substitution (MRS) are estimated. MRS indicates the trade-off between two attributes that characterize the good and thus the mutual importance of the attributes in question (14) is holding the overall utility level constant, $\partial V_{i}=\beta_{\partial x i}=0$ and MRS becomes

$$
M R S_{12}=-\frac{d x i 1}{d x i 2}=\frac{\beta 1}{\beta 2}
$$

When one of the attributes is a cost attribute, the MRS indicates the willingness-to-pay (WTP) for a change in the qualitative attribute, i.e. the marginal willingness-to-pay (MWTP), also known as 
part-worth. Let the price attribute be denoted as $p$. As income cancels out in linear price models hence the negative sign of the price variable, marginal WTP becomes,

$$
\operatorname{MWTP}_{i}=\frac{d x i}{d u}=\frac{d x i}{d p}=\frac{\beta x i}{-\beta p}
$$

Applying another functional form for the price, such as a log-linear, causes the calculation of MRS to change as the MRS estimates were then dependent on the absolute level of logged variables. This implies that MWTP depends upon the absolute level of utility(Lancaster, 1966).

\section{RPL model specification}

The assumption of IIA in the multinomial logit model (MNL) is hard to meet in real choice models. If the assumption of IIA is violated which can be tested using the Hausman and McFadden (1984) procedure, we have to resort to models that would relax this assumption. One such model is the random parameter logit model (RPL) also known as the mixed logit model (Train, 1998). The mixed logit model (MLM), as opposed to the multinomial logit model, allows for high flexibility by specifying taste coefficients to be randomly distributed across individuals and it accounts for unobserved heterogeneity of households in decision making (Campbell et al.,2011; Hensher and Greene, 2003; Kroon et al., 2014).

The Random Parameters logit model takes the multinomial logit model as a basis and simplifies it by allowing the coefficients of systematic variables to vary across the individuals. This is done through the division of unobservable component of the utility function into two: one which is correlated over alternatives and the second part is identically and independently distributed, as it is given by:

$$
U_{i j}=\beta X_{i j}+\delta i X_{i j}+\varepsilon_{i j}
$$

Where, $X_{i j}$ is a vector of observed attributes (Terracing, Conservation agriculture, and total cost ) of alternative within a choice set $\beta$, is the vector of coefficients of these attributes, $\delta n$ denotes the vector of $\mathrm{k}$ standard deviation parameters, and, $\varepsilon_{i j}$ the the random portion of utility. Thus, $\delta i X_{i j}+$ $\varepsilon_{i j}$. it is the unobserved portion of utility because of the influence of $\delta n$ which is correlated across individuals (Train, 1998). The probability of individual $\mathrm{i}$, choosing alternative $\mathrm{j}$ in a choice situation t, let's assume is expressed as follows:

$$
P\left(j / \delta_{i}\right)=\frac{\exp \left(\alpha_{j i}+\gamma_{j} z_{i}+\delta i X_{i j}\right)}{\sum_{\mathrm{j}=1}^{\mathrm{J}} \exp \left(\alpha_{j i}+\gamma_{j} z_{i}+\delta i X_{i j}\right)}
$$


Where, $\alpha_{j i}$ is a fixed or random alternative specific constant for $\mathrm{i}$ individuals and $\mathrm{j}$ alternatives $(\mathrm{j}=1, \ldots, \mathrm{J}), \gamma_{j} z_{i}$ is a vector of systematic parameters responsible for individuals characteristics, Sjidenotes a parameter vector which is randomly distributed over individuals, $z_{i}$ accounts for individual-specific characteristics, $X_{i j}$ is the vector of attributes and $\delta i$ is the individual-specific random disturbance of unobserved heterogeneity (Louviere et al., 2000a; Train, 1998). However, to estimate the RPL model, it is necessary to assume how the coefficients are distributed over the individuals (Train, 1997).

Thus, to relax the IIA assumption and further examine the sources of heterogeneity amongst farmers, in these stage random parameters logit was estimated as maintained by Train (2003), normally distributed parameters, means and standard deviations of the coefficients can provide information on to what extent respondents put either positive or negative value on the environmental attribute.

In contrast to the linear regression model, there is no single measure for the goodness of fit. In discrete choice models. One of the most well-known measures of goodness of fit is the McFadden $R^{2}$ (also termed pseudo $R^{2}$ )(Ryan, 2004). It is defined as follows:

$$
R^{2}=1-\frac{L L\left(R^{R}\right)}{L L\left(R^{U}\right)}
$$

The nominator is the value of the log-likelihood function at the estimated parameters and the denominator is its value when all the parameters are set equal to zero. According to (Hensher et al., 2005) and (McFadden, 1974), the rule of thumb for a good model in case of McFadden's Pseudo $\mathrm{R}^{2}$ should run 0.2 to 0.4

\section{Result and Discussion}

The demographic characteristic of household head includes age, sex, family size, and marital status. As shown from Table 4.1, minimum and maximum age of respondents were 19 and 65 respectively. The mean age of household heads who don't implement sustainable land management practices were 35.135 and mean age of household heads implementing sustainable land management practice was $35.865 \mathrm{p}$-value indicates that there is no significant mean difference on age between household heads who implement and who don't implement SLM practices.

According to (CSA, 2008) average family size of rural household head is 4.9 which is approximately 5 , based on data indicated in Table 4.1 shows the study area family size exceeds 
average national rural family size. The mean family size of farmerse who don't implement SLM practices was 7.09 and for farmers ${ }^{\text {ee }}$ who practice SLM practices was 7.11 According to Table 4.1 p-value for family size indicates that there is no significant mean difference on a family size of farmers ${ }^{\text {ee }}$ who implement and don't implement SLM practices.

\section{1: Demographic characteristics of respondents on continuous/discrete variables}

\begin{tabular}{|c|c|c|c|c|c|c|}
\hline \multirow{3}{*}{$\begin{array}{l}\text { Explanatory } \\
\text { variables }\end{array}$} & \multicolumn{4}{|c|}{ Land management practice } & \multirow[t]{2}{*}{ p-value } & \multirow[t]{2}{*}{ t-value } \\
\hline & $\overline{\min }$ & $\overline{\mathrm{Max}}$ & $\begin{array}{l}\text { Not } \\
\text { implementing } \\
\text { SLM }\end{array}$ & $\begin{array}{l}\text { Implementing } \\
\text { SLM }\end{array}$ & & \\
\hline & & & Mean & Mean & & \\
\hline Age of HHs & 19 & 65 & $\begin{array}{l}35.135 \\
(9.399389)\end{array}$ & $\begin{array}{l}35.865 \\
(9.600611)\end{array}$ & 0.556 & 0.59 \\
\hline $\begin{array}{l}\text { Family size of } \\
\text { HHs }\end{array}$ & 1 & 18 & $\begin{array}{l}7.09 \\
(3.51)\end{array}$ & $\begin{array}{l}7.11 \\
(3.49)\end{array}$ & 0.799 & 0.25 \\
\hline
\end{tabular}

Source: Own survey data (2020) Numbers in parenthesis indicates the standard deviation

\section{2: Demographic characteristics of respondents on dummy/categorical variables}

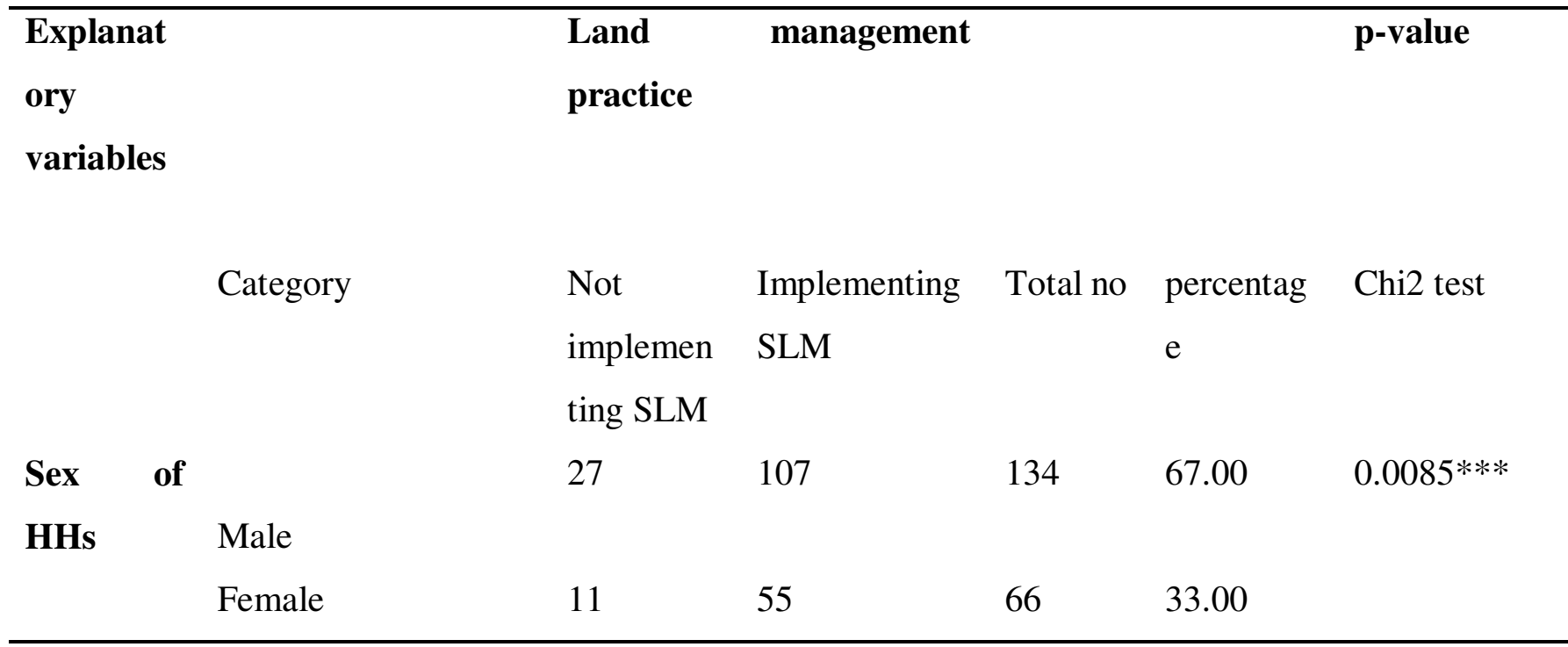




\begin{tabular}{lllllll}
\hline $\begin{array}{l}\text { Marital } \\
\text { status }\end{array}$ of & Single & 3 & 8 & 11 & 5.50 & $0.036^{* *}$ \\
HHs & Married & 35 & 149 & 184 & 92.00 & \\
& Divorce & 0 & 5 & 5 & 2.50 & \\
& & & & & & \\
Educatio & only read and write & 13 & 44 & 57 & 28.5 & $0.0064^{* *}$ \\
n level & does not read \& write & 9 & 51 & 60 & 30 & \\
& religious education & 9 & 44 & 53 & 26.5 & \\
& primary and above & 7 & 23 & 30 & 15 & \\
& Orthodox & 0 & 0 & 0 & 0 & $0.000^{* * *}$ \\
Religion & Muslim & 38 & 161 & 199 & 99.50 & \\
& Protestant & 0 & 0 & 0 & 0 & \\
& others & 1 & 0 & 1 & 0.50 &
\end{tabular}

Source: Own survey data (2020) Legend: * $\mathrm{p}<0.05 ; * * \mathrm{p}<0.01 ; * * * \mathrm{p}<0.001$

As can be seen from Table 4.2, from a total of 134 male household heads 27 respondents were not implementing SLM practices and 107 respondents were implementing SLM practices. Whereas from a total of 66 female household heads 11 were not implementing SLM practices and 55 respondents were implement SLM practices. The chi-square test showed that there is a statistical association between sex of household heads and decision to implement land management practices. Thus, from above Table 4.2 information, majority of household heads are male households. On the other wing, from a total of 38 households who don't implement SLM practices. Whereas from 162 households who implement SLM practices 149 are married, 8 unmarried (single), and 5 divorced. According to the above Table 4.2, chi-square test showed that there is a statistical association between marital status of household head and decision to implement SLM practices.

4. 3: Socio-Economic characteristics of the households on continuous/ discrete variables

\begin{tabular}{llll}
\hline $\begin{array}{l}\text { Explanatory } \\
\text { variables }\end{array}$ & Land management practice & p-value & t-value \\
\hline
\end{tabular}




$\begin{array}{lll}\min \text { Max } & \text { Not } & \text { Implementing } \\ & \text { implementing } & \text { SLM } \\ & \text { SLM } & \end{array}$

\begin{tabular}{|c|c|c|c|c|c|c|}
\hline & & & Mean & Mean & & \\
\hline $\begin{array}{l}\text { Landholding } \\
\text { size/timad }\end{array}$ & 4 & 35 & $\begin{array}{l}14.34211 \\
(7.010711)\end{array}$ & $\begin{array}{l}14.00617 \\
(6.175987)\end{array}$ & 0.2809 & 0.5811 \\
\hline $\begin{array}{l}\text { Off-farm/HH- } \\
\text { size }\end{array}$ & 0 & 4 & $\begin{array}{l}1.263158 \\
(.9207579)\end{array}$ & $\begin{array}{l}1.481481 \\
(.8357109)\end{array}$ & 0.0784 & $1.4212 * * *$ \\
\hline $\begin{array}{l}\text { On-farm/HH- } \\
\text { size }\end{array}$ & 0 & 12 & $\begin{array}{l}1.868421 \\
(.7040828)\end{array}$ & $\begin{array}{l}1.91358 \\
(1.160398)\end{array}$ & 0.4092 & $0.2299 * * *$ \\
\hline Livestock/tlu & 0 & 5.7 & $\begin{array}{l}.9336842 \\
(1.27399)\end{array}$ & $\begin{array}{l}0.8043827 \\
(1.175012)\end{array}$ & 0.7256 & 0.6007 \\
\hline $\begin{array}{l}\text { HHS } \\
\text { cost/month }\end{array}$ & 750 & 4500 & $\begin{array}{l}1663.158 \\
(689.1715)\end{array}$ & $\begin{array}{l}1822.716 \\
(784.9588)\end{array}$ & 0.1252 & 1.1527 \\
\hline
\end{tabular}

Source: Own survey data (2020) Number in parenthesis indicates standard deviation.

NB: Legend: $\mathrm{p}<0.05 ; * * \mathrm{p}<0.01 ; * * * \mathrm{p}<0.001$

The socio-economic characteristic of household head includes on-farm, off-farm activity, landholding size, household spending per month, and livestock holding. The response of sample household heads has been categorized as continuous/discrete and dummy/categorical variable and summarized in Table 4.2 and 4.3 respectively.

As indicated from above Table 4.3, landholding size is one socio-economic characteristics of household heads. The minimum landholding size of household head respondent was $4 \operatorname{timad}^{2}$ and maximum landholding size of household head respondents was 35 timad. The mean value for households who don't implement and who implement SLM practices were 14.34211 and 14.00617 respectively, also above Table reveals that there is no significant mean difference in landholding size between households implementing and don't implement SLM practices.

${ }^{2}$ One Timad $=1 / 4$ hectare 


\section{4: The major crop types cultivated in the study area}

\begin{tabular}{llll}
\hline Type of crop & Freq. & Percent & Cum. \\
Teff & 4 & 2.00 & 2.00 \\
Sorghum & 95 & 47.00 & 49.00 \\
Barly & 3 & 1.50 & 51.00 \\
Maize & 37 & 18.50 & 69.50 \\
Sorghum \& maize & 61 & 30.50 & 100.00 \\
Total & $\mathbf{2 0 0}$ & $\mathbf{1 0 0 . 0 0}$ & \\
\hline
\end{tabular}

Source: Own survey data (2020)

According to survey result in above table 47 percent household head where cultivate sorghum and it is the highly cultivated crop in study area as a camper to others crop next to both sorghum\& maize 30.50 percent and maize 18.5 percent only 5.9 percent. However, barely and Teff are least cultivated crop in study area. From this, we can conclude that maize and sorghum are commonly cultivated in study area.

\section{5: Nature of landform in the study area}

\begin{tabular}{llll}
\hline Landforms & Freq. & Percent & Cum. \\
\hline Flat & 126 & 63.00 & 63.00 \\
Rugged & 13 & 6.50 & 69.00 \\
Steep slope & 60 & 30.00 & 99.00 \\
Other & 1 & 0.50 & 100.00 \\
\hline Total & $\mathbf{2 0 0}$ & $\mathbf{1 0 0 . 0 0}$ & \\
\hline
\end{tabular}

Source: Own survey data (2020)

According to survey data, 63 percent respondents have plain landform and they are plowing on plain (flat) land and 30 percent have steep slope landform and rugged is least experienced in study area.

4. 6: Type Sustainable land management's practices and modern fertilizer adoption in the study area 


\begin{tabular}{lllllll}
\hline $\begin{array}{llll}\text { Fertilizer } \\
\text { adoption }\end{array}$ & Terracing & Crop-rotation & $\begin{array}{l}\text { Conserve } \\
\text { agriculture }\end{array}$ & Total & 0.5341 & 0.766 \\
Yes & 82 & 38 & 38 & 158 & \\
No & 24 & 10 & 8 & 42 & \\
\cline { 1 - 4 } Total & $\mathbf{1 0 6}$ & $\mathbf{4 8}$ & $\mathbf{4 6}$ & $\mathbf{2 0 0}$ & \\
\cline { 1 - 4 }
\end{tabular}

Source: Own survey data (2020)

According to above table 4.6, households who adopt modern fertilizer 82 use terracing, 38 croprotation and 38 adopt conserve agriculture as sustainable land management practices, on other hand households who don't adopt modern fertilizer also 24 adopt terracing, 10 crop-rotation, and 8 conserve-agriculture, but p-value indicate that there is no association between modern fertilizer and decision to adopt sustainable land management's.

\section{7: The awareness level of households' about the benefit of practicing SLM and their} presumptions for land degradation

\begin{tabular}{|c|c|c|c|c|c|}
\hline Severity & $\begin{array}{ll}\text { of } & \text { Sus }\end{array}$ & able 1 & nt's benefit & p-value & Chi2 \\
\hline degradation & Yes & No & Percent & $0.006^{* * *}$ & 1.8028 \\
\hline very sever & 23 & 15 & 19.00 & & \\
\hline sever & 62 & 24 & 43.00 & & \\
\hline Minor & 54 & 22 & 38.00 & & \\
\hline Total & 139 & 61 & 100 & & \\
\hline
\end{tabular}

Source: Own survey data (2020)

According to table 4.7 above, households who experience benefits of SLM 43 response that land severely degradation, also according to (FAO, 2018)4 - 7 percent of SSA has severely degraded highest proportion of any region in the world, 54 minor degradations and 23 very severe degradations, on others hand households who don't experience benefits of sustainable land management's 24 response that their land severely depredated, 22 minor degradations and 15 very severe degradations and p-value explain that there is a significant association between awareness level and presumption for land degradation.

\section{8: Extension services and usual solution for land degradation in the study area}




\begin{tabular}{|c|c|c|c|c|c|}
\hline \multirow{2}{*}{$\begin{array}{l}\text { Solution for land } \\
\text { degradation }\end{array}$} & \multicolumn{3}{|c|}{ Access of extension services } & \multirow{2}{*}{$\begin{array}{l}\text { p-value } \\
0.801\end{array}$} & \multirow{2}{*}{$\frac{\text { Chi2 }}{0.9994}$} \\
\hline & Yes & No & Percent & & \\
\hline shift cultivation & 77 & 73 & 75.00 & & \\
\hline Expanded to marginal & 21 & 19 & 20.00 & & \\
\hline \multicolumn{6}{|l|}{ land } \\
\hline off farm & 5 & 4 & 4.50 & & \\
\hline Others & 1 & 0 & 0.50 & & \\
\hline Total & 104 & 96 & 100 & & \\
\hline
\end{tabular}

Source: Own survey data (2020)

The above table 4.8 explain that from 104 who have access for extension ${ }^{3}$ services, 77 use shift cultivation as a solution for land degradation, 21 used to expand marginal land as a solution, 5 offfarm activity as a way for land degradation problem and 1 only other method, on another way from 96 total household head who do not have access to extension services, also 73 adopt shift cultivation, 19 expand to marginal land, 4 off-farm activity, and 0 other way, however, p-value indicate no significant difference between extension services and solution for land degradation As can be seen in Table 4.10, results reveal that random parameters logit model estimations reveal significant and large standard deviations for sustainable land management's attributes levels coefficients. This means that preference heterogeneity exists among farmers, comparing to the benchmark CL model which is reported in first column of Table 4.10. In both conditional logit and mixed logit model, almost all attributes except two attributes levels of terracing namely erosion reduction and soil moisture are significant. The results of mixed logit model are presented in Column 4 of Table 4.10 .

\section{9: Results from various discrete choice models}

\begin{tabular}{lllll}
\hline Variables & \multicolumn{1}{l}{ Cologit } & \multicolumn{3}{l}{ Mixlogit } \\
\cline { 2 - 5 } & Coefficient & S.E & Coefficient & S.E \\
& & & & \\
ASC & 21.692 & 1014.107 & 24.50 & 394 \\
\hline
\end{tabular}

${ }^{3}$ Extension by means including any chance of trainings related with land managements 


\begin{tabular}{lllll}
\hline Cost & $-0.000 * * *$ & 0.000 & $-0.000 * * *$ & 0.000 \\
Erosion & -0.672 & 0.710 & -0.663 & 0.714 \\
$\begin{array}{l}\text { reduction } \\
\text { Soil moisture }\end{array}$ & -0.155 & 0.716 & -0.162 & 0.720 \\
Pest reduction & $-2.025 * * *$ & 0.389 & $-2.087 * * *$ & 0.393 \\
& & & & \\
Increase fertility & $-1.736 * * *$ & 0.375 & $-1.748 * * *$ & 0.378 \\
Soil structure & $3.469 * * *$ & 0.658 & $3.519 * * *$ & 0.664 \\
Water quality & $3.012 * * *$ & 0.655 & $3.036 * * *$ & 0.657 \\
Air quality & $3.564 * * *$ & 0.658 & $3.592 * * *$ & 0.661 \\
Crop yield & $3.179 * * *$ & 0.657 & $3.152 * * *$ & 0.659 \\
LL & -696.827 & & -695.633 & \\
Pseudo R-squared & 0.603 & & & \\
AIC & 1413.655 & & & \\
\hline
\end{tabular}

Legend: * $\mathrm{p}<0.05 ; * * \mathrm{p}<0.01 ; * * * \mathrm{p}<0.001$

The positive and insignificant ASC coefficient indicates that respondents had a higher utility of SLM alternatives, but it depends upon costs of alternatives as compared to status quo ${ }^{4}$. The coefficient of cost was negative and significant indicating that respondents had higher utility of alternatives with minimum cost of attributes levels as a camper to status quo. The negative and insignificant coefficients of terracing attribute level namely erosion reduction and soil moisture show that respondents derived higher utility from others alternative of sustainable land management's. The households had higher utility from minimum level of pests, and lower cost level of natural fertilizer and positive and significant of soil structure, water quality, air quality, and crop yield attributes levels sustainable land management's.

\section{Estimation of willingness to pay}

According to (Howe, Bateman, \& Durbin, 2002) choice experiment method is compatible with utility maximization and demand theory. Marginal willingness to pay for an attribute in choice

\footnotetext{
${ }^{4}$ Shift cultivation in case of the study
} 
experiment is ratio of attribute coefficient and payment attribute coefficient (Morrison, Parkes, \& Vakhnenko, 1999). This result carries important policy implications as sustainable land management's, policymakers can identify most important features of sustainable land management's. The part-worth or marginal rate of substitution given in Table 4.11 shows the rate at which farmer/households trades-off one attribute according to its level for another. They attached more value to crop-rotation attribute levels namely pest reduction followed by increase fertility. Their marginal willingness to pay was lower for conserve-agriculture attributes level namely air quality followed by soil structure.

\section{10: MWTP for individual attributes levels}

\begin{tabular}{lll}
\hline Attributes levels & Coefficient & S.E \\
Erosion reduction & 844.103 & 915.19 \\
Soil moisture & 194.466 & 905.765 \\
Pest reduction & $2540.378 * * *$ & 685.724 \\
Increase fertility & $2178.389 * * *$ & 612.705 \\
Soil structure & $-4352.38 * * *$ & 1410.34 \\
Water quality & $-3778.595 * * *$ & 1297.94 \\
Air quality & $-4470.753 * * *$ & 1439.138 \\
Crop yield & $-3988.337 * * *$ & 1320.267 \\
\hline
\end{tabular}

Legend: $* \mathrm{p}<.05 ; * * \mathrm{p}<.01 ; * * * \mathrm{p}<.001$

Finally, the estimated total willingness to pay considering assumption of normal distribution, hence probit model was estimated to calculate probability of total willingness to pay (TWTP) for sustainable land management's taking three alternatives; two of them as action alternative and one as status-quo, in which TWTP was calculated for action alternative excluding status-quo as a baseline and study was found it significant and positive:

Total willingness to pay

\begin{tabular}{llll}
\hline \multirow{2}{*}{ Prediction } & Model 1 & Model 2 & TWTP \\
& 0.335279 & 0.329626 & 0.664905 \\
chi2 & 0.0000 & 0.0000 & --- \\
\hline
\end{tabular}




\begin{tabular}{llll}
\hline Pseudo R2 & 0.0419 & 0.1659 & ---
\end{tabular}

The positive and significant of household's total willingness to pay for SLM indicate that in any alternative or bundle of SLM which could improve their agricultural production they react positively and they will pay 66 percent and above cost of SLM bundle as a camper to status -quo namely shift cultivation to overcome any environmental degradation.

\section{11: Determinants of WTP results from demographic characteristics and socio-economic} data

\begin{tabular}{|c|c|c|c|}
\hline Types of SLM & Variables & Coef. & S.E \\
\hline \multirow[t]{11}{*}{ Crop _ rotation } & \multicolumn{3}{|c|}{ Terracing(base outcome) } \\
\hline & \multirow[t]{2}{*}{ Marital status } & 0.3688117 & .3688117 \\
\hline & & 0.7043175 & \\
\hline & Family size & 0.152833 & .1039898 \\
\hline & Land size & -0.0901526 & $.0441324 * *$ \\
\hline & Landform & -0.1576249 & .2200422 \\
\hline & Types of crop & -0.020529 & .0968868 \\
\hline & TLU & 0.2506467 & .1693345 \\
\hline & slm_benefit/awerness & 0.7288214 & .4453341 \\
\hline & fertlizer_adoption & 0.7040087 & .5030939 \\
\hline & agri_pro_spen & -0.4387373 & $.2284603 * *$ \\
\hline \multirow[t]{11}{*}{ Conserve_agriculture } & \multicolumn{3}{|c|}{ Terracing(base outcome) } \\
\hline & Marital status & 1.930096 & $.9824708 * *$ \\
\hline & Family size & 0.1774893 & $.1049375^{*}$ \\
\hline & Land size & -0.0218795 & .0454406 \\
\hline & Landform & 0.2716177 & $.2270752 *$ \\
\hline & Types of crop & 0.3631692 & $.1079144 * * *$ \\
\hline & TLU & -0.1597083 & .2035116 \\
\hline & slm_benefit/awerness & 0.6779522 & $.5185535 * *$ \\
\hline & fertlizer_adoption & 1.247225 & $.5285644 * *$ \\
\hline & agri_pro_spen & -0.9020745 & $.2883093 * * *$ \\
\hline & Constant & $-0.607 * * *$ & \\
\hline
\end{tabular}




\section{Pseudo R2 \\ 0.0644 \\ LR Chi2 28.27(p-value= \\ 0.0075)}

Legend: $* \mathrm{p}<.05 ; * * \mathrm{p}<.01 ; * * * \mathrm{p}<.001$

To identify determinants of farmers decision to implement sustainable land management practices by assuming types of sustainable land management's practices as dependent variables and different independents variables. However, only nine variables say to be significant from total of independents variables, overall model is highly significant in case of chi-square at less than $1 \%$.

\section{Marginal effects of multinomial logit (relative probability)}

Land form is significantly and positively determine sustainable land management's. Thus, relative probability of adopting conserve agriculture and crop rotation rather than terracing is 4 percent lower for steep slope landform with the same others SLM factors.

Agricultural production spends is significantly and negatively determining sustainable land management's. However it is insignificants in case of conserve-agriculture types of SLM with base of terracing. Thus, relative probability of adopting conserve-agriculture types of SLM rather than terracing is more than double. In short, spends their agricultural production for both personal and market is associated with an increase in relative probability of CA over terracing, but also a much lower in relative probability of crop rotation over terracing.

Types of crop is positively and significantly determine sustainable land managements. Thus, relative probability of adopting crop-ration and CA rather than terracing for selected types of crop is 3 percent lower for corresponding relative probability of sorghum \& maize with the same others SLM determinants.

Land size is negatively and significantly determine decision to implement's SLM. Thus, marginal effects of land size of farmers found to be significant and positive in case of crop rotation types of SLM. The relative probability of adopting crop-ration rather than terracing is a percent higher than for those corresponding relative probability of who own small land size which is same others SLM determinants. (Maiangwa, Ogungbile, Olukosi, \& Atala, 2010) and (Kifle, 2016) which reveals land size significantly affect adoption of sustainable land management.

The marginal effects of sustainable land management's benefits or awareness of farmers found to be significant and positive in case crop rotation types of SLM. Thus, relative probability of 
adopting crop-ration rather than terracing for those who say Yes 7 percent higher than for corresponding relative probability of who say No with same others SLM determinants.

Marital status is positively and significantly determine sustainable land management's. Therefore, average probability of conserve agriculture is 0.08128 if married and 0.01238 if not married, a difference of 0.0688 , so the probability of conserve agriculture is on average just over six percentage points higher for married person with respects to base outcome.

Family size is positively and significantly determine sustainable land management's. Therefore, average marginal effect of family size on conserve agriculture is actually positive. This means that probability of family size is on average about a percent higher for high family size of owners than for small size of family with same others factors of land.

\section{Conclusion}

The results of the study show that sustainable land management's related attributes, some demographics characteristics variables, and socio-economic characteristics variables of respondent were vital in determining preferences for adopting a bundle of sustainable land management. Terracing attributes level which is reduce soil erosion and increase soil moisture was found to be insignificant to affect decision to adopt SLM practices, and its reason that terracing most of the time it used to be adopted on gentle-slop landform, and similar with study by (Deichert et al., 2017) and more than 63 percent of respondents assure that their landform are flat. However, crop-rotation attributes levels are negatively and significantly affected probability of households willingness to pay for sustainable land management' and conserve-agriculture attributes levels positively and significantly affected probability of household's decision to implements' sustainable land management's ..

Thus, all discrete choice attributes including insignificant, households were put high price for croprotation attributes and lower for conserve-agriculture, which is supported by response for their landform as flat and type of crop households used to cultivate frequently was found to highly significant to determine households WTP in socio-economic analysis of multinomial logit. In totality, the study concluded that household's willingness to pay more than 66 percent cost for any sustainable land management bundle to improve agricultural production by examining their total willingness to pay for SLM. Family size and marital status in socio-demographic characteristics and landform, type of crop, awareness, fertilizer, livestock, and land size was found to be vital 
determinant households willingness to pay and was confirmed by others study (Adimassu et al., 2012), (Arega et al., 2018), (Deichert et al., 2017).

The total willingness to pay for sustainable land management practices practiced in study area was positive and significant, indicating need for collaboration or active participation of farmers with agricultural office workers or agricultural experts to enhance high involvement for sustainable land management practices, Any sustainable land management's project, to design the bundle of SLM should consider landform targeted area, regional state, zonal administration, woreda agriculture and environmental protection bodies should increase their intervention to support SLM implementation especially the crop-ration practices in study area and woreda agricultural office should disseminate important farm equipment to farmers to strengthen continuous work on sustainable land management practices.

\section{Reference}

Abebe, S., Dagnew, A., Zeleke, V., Eshetu, G., \& Cirella, G. (2019). Willingness to pay for watershed management. Resources, 8(2), 77.

Adimassu, Z., Kessler, A., \& Hengsdijk, H. (2012). Exploring determinants of farmers' investments in land management in the central rift valley of Ethiopia. Applied Geography, 35(1-2), 191-198.

Alberini, A., \& Kahn, J. (2006). Handbook on contingent valuation: Edward Elgar Publishing.

Arega, M., Temesgen, D., \& Mansingh, J. (2018). Sustainable land management practices and their impacts on the livelihoods of smallholder farmers in the benishangul gumuz region of Ethiopia. Sustainable Land Management Practices and their Impacts on the Livelihoods of Smallholders Farmers in Benishangul Gumuz Region of Ethiopia (December 19, 2018).

Asrat, P., Belay, K., \& Hamito, D. (2004). Determinants of farmers' willingness to pay for soil conservation practices in the southeastern highlands of Ethiopia. Land Degradation \& Development, 15(4), 423-438.

Balmford, A., Fisher, B., Green, R.E., Naidoo, R., Strassburg, B., Turner, R.K., \& Rodrigues, A.S. (2011). Bringing ecosystem services into the real world: An operational framework for assessing the economic consequences of losing wild nature. Environmental and Resource Economics, 48(2), 161-175.

Barry, P.J., Sherrick, B.J., \& Zhao, J. (2009). Integration of var and expected utility under departures from normality. Agricultural Economics, 40(6), 691-699.

Bliemer, M.C., \& Rose, J.M. (2010). Construction of experimental designs for mixed logit models allowing for correlation across choice observations. Transportation Research Part B: Methodological, 44(6), 720-734.

Böttcher, H., Freibauer, A., Scholz, Y., Gitz, V., Ciais, P., Mund, M., . . . Schulze, E.-D. (2012). Setting priorities for land management to mitigate climate change. Carbon balance and management, $7(1), 5$.

Boyd, J. (2007). Nonmarket benefits of nature: What should be counted in green GDP? Ecological Economics, 61(4), 716-723.

Commission, F.D.R.o.E.P.C. (2008). Summary and statistical report of the 2007 population and housing census. Addis Ababa, Ethiopia. 
Deichert, G., Gedamu, A., \& Nemomsa, B. (2017). Role of sustainable land management (SLM) in adapting to climate variability through agricultural practices - experiences from Ethiopian highlands Climate change adaptation in Africa (pp. 475-492): Springer.

Edwards-Jones, G., Davies, B., \& Hussain, S.S. (2009). Ecological economics: An introduction: John Wiley \& Sons.

Eshetia, H. (2018). Factors influencing farmers"' decision in implementing sustainable land management practices in erosion-prone areas of east gojjam zone, Ethiopia. Addis Ababa University.

Flynn, T.N., Louviere, J.J., Peters, T.J., \& Coast, J. (2007). Best-worst scaling: What it can do for health care research and how to do it. Journal of health economics, 26(1), 171-189.

Freeman, A.M. (1992). The measurement of environmental and resource values: Theory and methods: Resources for the Future.

Freeman III, A. (2003). The measurement of environmental and resource values: Theory and methods, resources for the future inc. Washington $D C$.

Gessesse, B., Bewket, W., \& Bräuning, A. (2019). Land use and land cover transformation and its implication on land degradation: The case of modjo watershed, Ethiopia Extreme hydrology, and climate variability (pp. 503-518): Elsevier.

Hagos, A., \& Geta, E. (2016). Review of smallholders agriculture commercialization in Ethiopia: What are the driving factors to focused on? Journal of Development and Agricultural Economics, 8(4), 65-76.

Harris, J.M., \& Roach, B. (2017). Environmental and natural resource economics: A contemporary approach: Routledge.

Hensher, D.A., Rose, J., \& Greene, W.H. (2005). The implications on willingness to pay of respondents ignoring specific attributes. Transportation, 32(3), 203-222.

Horna, J.D., Smale, M., \& Von Oppen, M. (2007). Farmer's willingness to pay for seed-related information: Rice varieties in Nigeria and Benin. Environment and Development Economics, 12(6), 799-825.

Howe, K., Bateman, A., \& Durbin, R. (2002). Quick tree: Building huge neighbor-joining trees of protein sequences. Bioinformatics, 18(11), 1546-1547.

Jaynes, J., Ding, X., Xu, H., Wong, W.K., \& Ho, C.M. (2013). Application of fractional factorial designs to study drug combinations. Statistics in medicine, 32(2), 307-318.

Johnson, R., \& Orme, B. (2003). Getting the most from CBC. Sequim: Sawtooth Software Research Paper Series, Sawtooth Software.

Kassie, m., Pender, j., yesuf, m., köhlin, g., buff stone, r., zikhaki, p., \& mulugeta, e. (2008). Sustainable land management practices improve agricultural productivity: Evidence on using reduced tillage, stone bunds, and chemical fertilizer in the Ethiopian highlands: Environmental for Development, EFD Policy Brief, Stockholm, Sweden.

Kifle, T. (2016). Land management practices and their contribution to livelihoods and land resources conservation in bale eco-region, southeastern Ethiopia msc thesis.

Lamesgin, T., Degye, G., \& Lemma, Z. (2017). Households' willingness to pay for soil conservation practices on cultivated land in south achefer district, amhara national regional state of ethiopia: A contingent valuation approach. Haramaya University.

Lancaster, K.J. (1966). A new approach to consumer theory. Journal of political economy, 74(2), 132-157.

Lanckriet, S., Derudder, B., Naudts, J., Bauer, H., Deckers, J., Haile, M., \& Nyssen, J. (2015). A political ecology perspective of land degradation in the north ethiopian highlands. Land Degradation \& Development, 26(5), 521-530.

Maiangwa, M., Ogungbile, A., Olukosi, J., \& Atala, T. (2010). Adoption of chemical fertilizer for land management in the north-west zone of nigeria. Tropical Agricultural Research and Extension, 10.

McFadden, D. (1974). Conditional logit analysis of qualitative choice behaviour”. In frontiers in econometrics, ed. P. Zarembka.(new york: Academic press).

McFadden, D. (1980). Econometric models for probabilistic choice among products. Journal of Business, S13-S29. 
Megerssa, G.R., \& Bekere, Y.B. (2019). Causes, consequences and coping strategies of land degradation: Evidence from ethiopia. Journal of Degraded and Mining Lands Management, 7(1), 1953-1957.

Miheretu, B.A., \& Yimer, A.A. (2017). Determinants of farmers' adoption of land management practices in gelana sub-watershed of northern highlands of ethiopia. Ecological Processes, 6(1), 19.

Morrison, A., Parkes, E., \& Vakhnenko, V. (1999). The n loop soliton solution of the vakhnenko equation. Nonlinearity, 12(5), 1427.

Nkonya, E., Mirzabaev, A., \& Von Braun, J. (2016). Economics of land degradation and improvement: A global assessment for sustainable development: Springer Open Cham, Germany.

Nyandiga, C., \& Currea, A.M. (2017). Community approaches to sustainable land management and agroecology practices: United Nations Development Programme.

Olana, H. (2014). Challenges of soil and water conservation practices and measure to be undertaken the case of wuchale district north shewa zone, oromia regional state, ethiopia. Addis Ababa University.

Pender, J., Gebremedhin, B., \& Haile, M. (2002). Livelihood strategies and land management practices in the highlands of tigray.

Rolfe, J., Windle, J., \& Bennett, J.W. (2008). Designing choice experiments to incorporate tests for geographic scale and scope differences.

Ryan, M. (2004). Discrete choice experiments in health care: British Medical Journal Publishing Group.

Schreinemachers, P., \& Berger, T. (2006). Land use decisions in developing countries and their representation in multi-agent systems. Journal of land use science, 1(1), 29-44.

Street, D.J., Burgess, L., Viney, R., \& Louviere, J. (2008). Designing discrete choice experiments for health care Using discrete choice experiments to value health and health care (pp. 47-72): Springer.

Train, K. (1998). Recreation demand models with taste variation over people. Land Economics, 74(2), 230-239.

Workie, L.T. (2017). Households'willingness to pay for soil conservation practices on cultivated land in south achefer district, amhara national regional state of ethiopia: A contingent valuation approach.

Zewdu, T., \& Desta, A.G. (2015). Assessment of feed resources and grazing land condition in gozamen district, east gojjam zone, amhara region. Haramaya University. 
Figures

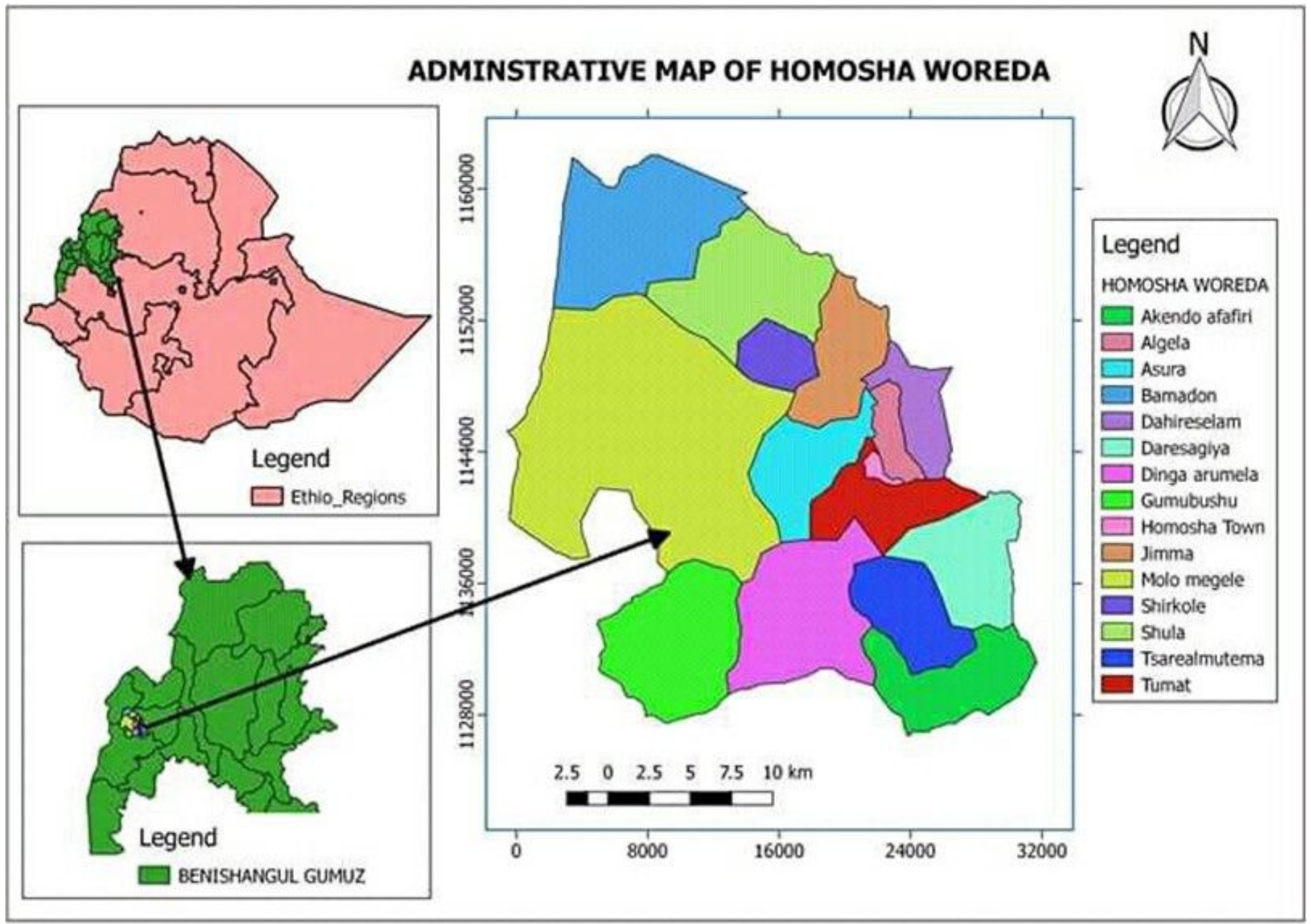

Figure 1

Figure 1 